\title{
表面波の回折散乱に対する有限要素解析法* \\ FINITE ELEMENT ANALYSIS OF SURFACE \\ WAVE DIFFRACTION AND SCATTERING
}

\author{
坂 井藤 一**.月 岡 康 一*** \\ By Fujikazu SAKAI and Koichi TSUKIOKA
}

\section{1. まえがき}

一般に平面 2 次元の表面波動を取扱 5 問題は, その解 析対象領域の形状により内部問題と外部問題に分けるこ とができる．前者は湖沼や液体タンクなど閉じた領域に おける振動現象を取扱うものであるのに対して, 後者は 海洋などの開いた領域における波動伝播現象を取扱うも のである. 後者においては解析対象領域が無限領城とな るので, 定常波動問題の場合には, 無限遠方の境界条件 として Sommerfeld の放射条件が課せられる.

物体の存在によって生ずる波動の回折散乱現象は外部 問題に含まれる. その中には, 解析関数を用いて解が得 られている古典的問題がいくつかある. すなわち，防波 堤による回折散乱問題に対しては, Sommerfeld による 光の半無限直線壁による回折問題の厳密解 ${ }^{2)}$ を忘用した 研究がある. Penny and Price ${ }^{3)}$ はこの厳密解が半無限 防波堤による回折散乱問題に適用できることを示し， Puttnam and Arthur ${ }^{4}$ はその近似解を提案すると共に 実験的検討を行った. また Blue and Johnson ${ }^{5)}$ はこの 解を重ね合わせることによって両翼防波堤による回折散 乱問題を解析し, 田中 ${ }^{6)}$ は島状防波堤も含めたいろいろ な防波堤配置の場合の 回折散乱問題を解析した.さら に, 最近では三井ら”が一連の研究において海岸構造物 不連続部における波高分布を解析し, 近似理論なども提 案している.

一方, 最近海洋構造物への関心が高まるにつれて, 柱 状構造物による回折散乱問題もますます重要な課題とな ってきている.これを解析的に取扱 5 には，FourierBessel 展開を用いることが多い. MacCamy and Fuchs ${ }^{8)}$ および田中 ${ }^{9}$ は円柱まわりの波の問題を解析し，Mo-

\footnotetext{
* 本論文の一部は, 文献 1) において発表された.

** 正会員 工博 川崎重工業 (株) 鉄構事業部開発設計部

*** 正会員 工修 川崎重工業 (株) 鉄構事業部開発設計部
}

moi $^{10)}$ はさらに複雑な問題を buffer domain 法とよぶ 手法を用いて解析している. また, 棈円柱による回折散 乱問題も, 散乱波を Mathieu 関数で級数展開すること により解析される. 合田ら ${ }^{11}$ は棈円柱および島状防波堤 による回折散乱問題をこの方法によって議論している. これらの方法とは別に, 和田 ${ }^{12)}$ は積分方程式をWienerHopf 解法で扱う Jones の方法を用いて, 回折散乱問題 の解を得る方法を述べている.

以上はいずれも解析関数を用いた古典的な方法といえ るものである.これは極めて特殊な場合にしか解を得る ことができないので, 任意の地形や構造物形状に応じた 解を求めるには適さない, その反面, 本質的な波動特性 を理解する上で有用なアナログ情報を提供するので, 現 在でもその重要性はいささかも失われていない.

これに対して, コンピュータの発達に伴い離散化手法 による数值シミュレーションが考えられるよらになっ た. 特に定常波動問題では, Green 関数を利用すること により支配方程式を積分方程式に変換し, それを離散化 して解く方法が用いられるようになった.この例とし $\tau$, Biesel et Ranson ${ }^{13)}$, Barailler et Gailland ${ }^{14)}$,

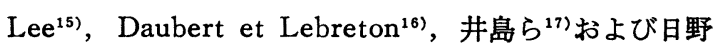
ら ${ }^{18)}$ の研究があげられる.この方法は, 任意の地形およ び構造物形状に対して適用可能であるが, 簡単に水深変 化を考慮しにくいという難点を有する．ただし，Barailler らの方法はこの点も克服しており, 注目に価するも のである.

非定常問題では, 基礎微分方程式を直接離散化する差 分法 ${ }^{19)}$ か, 変分原理あるいは重みつき残差法に基づく有 限要素法 ${ }^{20)}$ によらざるを得ないのが現状であろう. 特に 後者は最近発展を遂げた手法であるが, 前者よりも一般 性があるといってよいと思われる. また，これらは定常 波動問題に対しても有用であるが, その点については従 来あまり研究がなされていないようである.ここでは, 定常波動の回折散乱現象に対する有限要素解析法につい 
て述べることにする.なお, 議論を進めるにあたっては 平面 2 次元波動を主眼とするが，その手法はより一般的 にも通用するものである。

前述したように，無限領域に打ける定常波動問題にお いては, 無限遠で放射条件が課せられる.これは, 地形 変化や構造物の存在により発生するかく乱波が, かく乱 源から十分離れた地点で一様な外向きの進行波となるこ とを示すものである. この放射条件を解析的満足する 関数については, 定常波動問題の Green 関数の研究と して古くから検討されており，いくつかの関数が提案さ れている ${ }^{21}$. ところが, 差分法や有限要素法のような数 值シミュレーション手法においては, この無限遠におけ る境界条件の取扱いがなかなか面倒である. 有限要素法 においては，Zienkiewicz ${ }^{22)}$ および $\mathrm{Bai}^{23)}$ によって放 射条件をそのまま有限地点における境界条件として用い る考え方が示された.この方法は, 散乱波の減衰が幾何 級数的に速い場合には問題ないが, 2 次元および 3 次元 の回折散乱解析においては一般に減衰が遅く, 対象領域 を大きくとる必要が生じてくる.

これに対して, 有限要素法に扔いて解析関数を利用す る方法が考えられる.これは, 無限遠で放射条件を満足 する解析解を有限地点に設けられた仮想境界において FEM に接続させることによって, 有限要素法で解析す る領域をできるだけ小さくしょうとするものである.こ れには吹出しを未知数として積分方程式を用いた Berkhoff ${ }^{24)}$ の研究, 固有関数展開を hybrid 変分原理を用 いて接続する Chen and $\mathrm{Mei}^{25)}$, Bai and Yeung ${ }^{26)}$, 瀬戸・山本 ${ }^{27)}$ などの研究がある.

本論で示す考え方は，Green 関数を利用することによ り積分方程式を導き, これを境界条件として有限要素解 析するものである. この方法は, Berkhoff の方法と等 価であるが，無用な吹出しを求める必要がない，本論の 考え方の特徴は, Lee などの積分方程式法と有限要素法 を結びつけた点にあると思われ，後に述べるように積分 方程式の変分原理による解法, あるいは別所の変分原理 のより一般化した形と見ることができよう。

本報告では，まず本有限要素法の基礎理論を述べ, 次 にその応用として水中に直立した円柱, 棈円柱, 長方形 柱㧍よび平板などによる回折散乱問題を解析し, 従来得 られている解との比較を行っている. その結果から見 て, 本手法の妥当性は検証されたものと思われる.

\section{2. 基礎理 論}

\section{（1）基礎方程式}

非圧縮, 非粘性, 非回転の仮定の下に平面 2 次元微小
振幅波を取扱う．現象が時間的に調和であるとすると， 水面変動の振幅 $\eta$ 注次の Helmholtz 方程式で与えられ る.

$$
\nabla^{2} \eta+k^{2} \eta=0 \text { in } \Omega
$$

ただし, $\Omega$ は対象領域, $\nabla^{2}$ は $x-y$ 平面における Laplacian, $k$ は角波数である. $k$ 唃振動数 $\sigma$ および水深 $h$ により次式で与えられる.

$$
\sigma^{2}=g k \tanh k h
$$

ここでは, 式 (1) を不透過壁 $S_{W}$ およびかく乱波か ら十分離れた無限遠とみなせる地点の境界 $S_{R}$ に囲まれ た領域 $\Omega$ に捛いて解くことにする (Fig. 1).この場合 の境界条件は，それぞれ次式で与えられる.

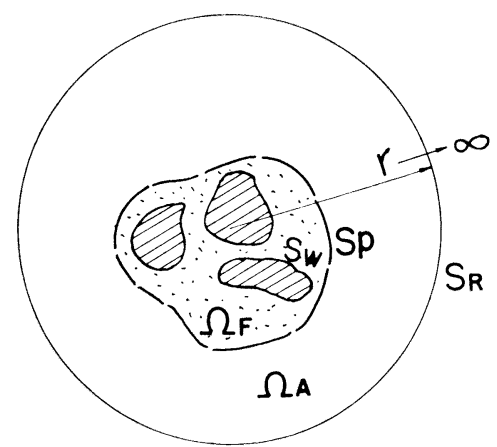

Fig. 1 Analyzed Region

$$
\begin{aligned}
& \eta_{, n}=0 \text { on } S_{W} \\
& \lim _{r \rightarrow \infty} \sqrt{r}\left(\eta_{s, r}-i k \eta_{s}\right)=0 \text { on } S_{R}
\end{aligned}
$$

ここで， $\eta_{s}$ は散乱波を表わし（），～$＼mathrm{~ は ~} \Omega$ の境界に対 する外向法線方向座標 $n$ による微分を示す. 式 (4) は，いわゆる Sommerfeld の放射条件である.

解析にあたっては, 全領域 $\Omega$ を仮想境界 $S_{P}$ によっ $\tau \mathrm{FEM}$ 領域 $\Omega_{F}$ と解析解領域 $\Omega_{A}$ に分割する. 前者 は地形や水深の変化および任意形状構造物などのかく乱 源の存在が許される閉領域であり, 後者はそのようなか 〈乱源のない一定水樑の無限領域とする. 両者の境界に おける連続条件は, 次のようになる。

$$
\begin{aligned}
& \eta_{F}=\eta_{A} \text { on } S_{P} \\
& \eta_{F, n}=-\eta_{A, n} \text { on } S_{P}
\end{aligned}
$$

ここで， $\eta_{F}$ および $\eta_{A}$ はそれぞれ $\Omega_{F}$ および $\Omega_{A}$ にお ける振幅を示す.

\section{（2）変分原理}

$\eta_{A}$ を基本波 $\eta_{0}$ と散乱波 $\eta_{S}$ の和として次のように表 わす.

$$
\eta_{A}=\eta_{0}+\eta_{S}
$$

ここで, 基本波 $\eta_{0}$ とは地形や構造物などのかく乱源が ない場合の波で既知であるから， $\eta_{S}$ を求めれば $\eta_{A}$ は 決定される. $\eta_{0}$ は独自に方程式 (1) を満足するので, 
$\eta_{S}$ も式 (1) を満たさねばならない.

$\eta_{F}$ および $\eta_{S}$ の満足すべき基礎方程式 と境界条件式 を整理すると, 次のようになる.

$$
\begin{aligned}
& \nabla^{2} \eta_{F}+k^{2} \eta_{F}=0 \text { in } \Omega_{F} \\
& \eta_{F, n}=0 \text { on } S_{W} \cdots \cdots \ldots \ldots . \\
& \nabla^{2} \eta_{S}+k^{2} \eta_{S}=0 \text { in } \Omega_{A} \\
& \eta_{S, n}-i k \eta_{S}=0 \text { on } S_{R} \cdots \cdots \\
& \eta_{F, n}=-\eta_{0, n}-\eta_{S}, n \text { on } S_{P} \\
& \eta_{F}=\eta_{0}+\eta_{S} \text { on } S_{P}
\end{aligned}
$$

$\eta$ を複素表示すると共に, 式 (8)〜 (12) に対して次の 汎関数 $\chi$ を考える.

$$
\begin{aligned}
& \chi=\frac{1}{2} \int_{\Omega_{F}}\left\{\left(\nabla \eta_{F}\right)^{2}-\left(k \eta_{F}{ }^{C}\right)^{2}\right. \\
& \left.-\left(\nabla \eta_{F} S\right)^{2}+\left(k \eta_{F}\right)^{2}\right\} d \Omega \\
& +\frac{1}{2} \int_{\Omega_{A}}\left\{\left(\nabla \eta_{S}{ }^{C}\right)^{2}-\left(k \eta_{S}{ }^{C}\right)^{2}\right. \\
& \left.-\left(\nabla \eta_{S} S\right)^{2}+\left(k \eta_{S}{ }^{S}\right)^{2}\right\} d \Omega \\
& +\int_{s_{R}} k \eta_{S} s_{\eta s} c d S \\
& +\int_{s_{P}}\left(\eta_{0},{ }^{c} \cdot \eta_{S}{ }^{c}-\eta_{0},{ }^{s} \cdot \eta_{S}{ }^{s}\right) d S
\end{aligned}
$$

ただし,サフィックス $C, S$ はそれぞれ複素数の実 部, 虚部を示す. また, 式（13）は付帯条件として課さ れる. 第 2 項の部分積分を実行すると，

$$
\begin{aligned}
& \chi=\frac{1}{2} \int_{\Omega_{F}}\left\{\left(\nabla \eta_{F}{ }^{c}\right)^{2}-\left(k \eta_{F}{ }^{c}\right)^{2}\right. \\
& \left.-\left(\nabla \eta_{F} S\right)^{2}+\left(k \eta_{F}\right)^{2}\right\} d \Omega \\
& -\frac{1}{2} \int_{\Omega_{A}}\left\{\left(\nabla^{2} \eta_{S}{ }^{C}+k^{2} \eta_{S}{ }^{C}\right) \cdot \eta_{S}{ }^{C}\right. \\
& \left.-\left(\nabla^{2} \eta_{S}{ }^{S}+k^{2} \eta_{S} S^{\prime}\right) \cdot \eta_{S} S\right\} d \Omega \\
& +\frac{1}{2} \int_{S_{R}}\left\{\left(\eta_{S, n} c+k \eta_{S} s\right) \cdot \eta_{S} c\right. \\
& \left.-\left(\eta_{S},{ }^{s}-k \eta_{S}{ }^{c}\right) \cdot \eta_{S}{ }^{s}\right\} d S \\
& +\frac{1}{2} \int_{S_{P}}\left\{\left(\eta_{S}{ }^{c} \cdot \eta_{S, n}{ }^{c}-\eta_{S}{ }^{s} \cdot \eta_{S},{ }_{n}{ }^{s}\right)\right. \\
& \left.+2 \cdot\left(\eta_{0, n}{ }^{C} \cdot \eta_{S}{ }^{C}-\eta_{0},{ }^{s} \cdot \eta_{s}{ }^{s}\right)\right\} d S
\end{aligned}
$$

となることから，访として式 (10),(11) を満足する関 数をとるならば, 上式は次のようになる.

$$
\begin{aligned}
& \chi=\frac{1}{2} \int_{\Omega_{F}}\left\{\left(\nabla \eta_{F} c\right)^{2}-\left(k \eta_{F}{ }^{C}\right)^{2}\right. \\
& \left.-\left(\nabla \eta_{F}{ }^{S}\right)^{2}+\left(k \eta_{F} S\right)^{2}\right\} d \Omega \\
& +\frac{1}{2} \int_{S_{P}}\left\{\left(\eta_{S}{ }^{c} \cdot \eta_{S, n}{ }^{c}-\eta_{S} s \cdot \eta_{S},{ }_{n}{ }^{s}\right)\right. \\
& \left.+2 \cdot\left(\eta_{0},{ }_{n}{ }^{C} \cdot \eta_{S}{ }^{C}-\eta_{0},{ }_{n}{ }^{s} \cdot \eta_{S}{ }^{s}\right)\right\} d S
\end{aligned}
$$

ところで, 式 (10) および（11）を満足すべき $\eta_{S}$ は, Green 関数を利用して次のように導くことができる.す なわち, Green 関数として,

$$
G(P, Q)=H_{0}^{(2)}(k r)
$$

を考える（ただし， $H_{0}{ }^{(2)}(k r)$ は 0 次の第 2 種 Hankel
関数, $r$ は 2 点 $P, Q$ 間の距離である) と, $G(P, Q)$ は次式を満足する。

$$
\begin{aligned}
& \nabla^{2} G+k^{2} G=0 \text { in } \Omega_{A} \ldots \ldots \\
& G,,_{n}-i k G=0 \text { on } S_{R} \\
& \operatorname{Im}[G] \underset{r \rightarrow 0}{\rightarrow}-(2 / \pi) \cdot \ln (k r)
\end{aligned}
$$

ただし, Im[ ] は虚部をとることを示す.

領域 $\Omega_{A}$ において次の Green の公式を適用する.

$$
\begin{aligned}
& \int_{\Omega_{A}}\left(\eta_{S} \cdot \nabla^{2} G-G \cdot \nabla^{2} \eta_{S}\right) d \Omega \\
& \quad=\int_{S_{R}+S_{P}+S_{0}}\left(\eta_{S} \cdot G,_{n}-G \cdot \eta_{S},_{n}\right) d S \cdots
\end{aligned}
$$

ただし， $S_{0}$ は特異点を囲む微小円の円周である．こ こで， $\eta_{S}$ に対する式 (10) および (11)，Gに対する式 (18) および（19）を考慮すれば，特異点の性質 (20)を 用いて点 $P$ における振幅 $\eta_{S}(P)$ は次のように求められ る.

$$
\begin{array}{r}
\eta_{S}(P)=\frac{i}{4} \int_{S_{P}}\left(\eta_{S} \cdot G,_{n}-G \cdot \eta_{S}, n\right) d S \text { in } \Omega_{A} \\
\ldots \ldots \ldots \ldots \ldots \ldots . \cdots \cdots \\
\eta_{S}(P)=\frac{i}{2} \int_{S_{P}}\left(\eta_{S} \cdot G,_{n}-G \cdot \eta_{S},{ }_{n}\right) d S \text { on } S_{P}
\end{array}
$$

式 (23) は $\eta_{S}$ に関する積分方程式である.これを $\eta_{S, n}$ について逆変換すれば, 作用素を $P$ として,

$$
\eta_{S, n}=P \cdot \eta_{S} \text { on } S_{P}
$$

複素表示すると次のようになる

$$
\left.\begin{array}{l}
\eta_{S, n}{ }^{C}=P^{C} \cdot \eta_{S}{ }^{C}-P^{S} \cdot \eta_{S}{ }^{s} \\
\eta_{S, n}{ }^{s}=P_{S} \cdot \eta_{S}{ }^{c}+P^{C} \cdot \eta_{S}{ }^{s}
\end{array}\right\} \text { on } S_{P}
$$

上式および式 (13) を式 (16) に適用することにより， 最終的に次の汎関数が得られる.

$$
\begin{aligned}
& \chi=\frac{1}{2} \int_{\Omega_{F}}\left\{\left(\nabla \eta_{F} C\right)^{2}-\left(k \eta_{F} C\right)^{2}\right. \\
& \left.-\left(\nabla \eta_{F} S\right)^{2}+\left(k \eta_{F} S\right)^{2}\right\} d \Omega \\
& +\frac{1}{2} \int_{S_{P}}\left\{( \eta _ { F } { } ^ { C } - \eta _ { 0 } c ) \cdot \left\{P^{C} \cdot\left(\eta_{F}{ }^{C}-\eta_{0}{ }^{C}\right)\right.\right. \\
& \left.-P^{S} \cdot\left(\eta_{F}{ }^{S}-\eta_{0}{ }^{S}\right)+2 \eta_{0},{ }_{n}{ }^{C}\right\} \\
& -\left(\eta_{F}{ }^{S}-\eta_{0}{ }^{S}\right) \cdot\left\{P^{S} \cdot\left(\eta_{F}{ }^{C}-\eta_{0}{ }^{C}\right)\right. \\
& \left.+P^{C} \cdot\left(\eta_{F}{ }^{S}-\eta_{0}{ }^{S}\right)+2 \eta_{0, n}{ }^{S}\right\} d S
\end{aligned}
$$

汎関数式 (26) の停留条件から Euler 方程式として 式(8), 自然条件として式 (9) および式 (12) を得る. 特に, $\Omega_{F}$ 領域がない場合には, 自然条件として,

$$
P \cdot\left(\eta_{F}-\eta_{0}\right)+\eta_{0, n}=0
$$

すなわち次式を得る.

$$
\eta_{S}=\frac{i}{2} \int_{S_{P}}\left(\eta_{S} \cdot G,_{n}+G \cdot \eta_{0, n}\right) d S \text { on } S_{P} \cdots
$$

これは, 式 (23) で $\eta_{S, n}=-\eta_{0, n}$ とおいたものとなる.

式 (28) のような積分方程式から汎関数を導いて変分 
原理を展開する考え方は, 航空工学の分野における翼解 析問題に利用されている ${ }^{28}$. また，水波の問題では日野 $ら^{18)}$ が Galerkin 法など重みつき残差法の適用を行って いるが，対称核の性質を利用した汎関数の存在には触れ ていない.ここで展開した変分原理はそれらと少し形式 が異なるものであり，さらに内部の FEM 領域との接続 を考えているので，より一般化したものと見なすことが できる*.

なお, 沉関数 (26) は式 (25) における対称作用素の 性質から導かれるものであり，任意形状の $S_{P}$ に対して は必ずしもこの対称性は成り立たなくなる，その際に は，重みつき残差法などを利用して変分式を導かねばな らない，たとえば，Galerkin 法では沉関数 (26) の停 留原理の代りに，次の変分式を用いればよい，

$$
\begin{aligned}
& \int_{\Omega_{F}}\left\{-\left(\nabla^{2} \eta_{F}{ }^{c}+k^{2} \eta_{F}{ }^{c}\right) \cdot \delta \eta_{F}{ }^{c}\right. \\
& \left.+\left(\nabla^{2} \eta_{F}{ }^{S}+k^{2} \eta_{F}{ }^{S}\right) \cdot \delta \eta_{F}{ }^{S}\right\} d \Omega \\
& +\int_{S_{P}}\left[\left\{P^{C} \cdot\left(\eta_{F}^{C}-\eta_{0}^{C}\right)-P^{S} \cdot\left(\eta_{F}^{S}-\eta_{0}{ }^{S}\right)\right.\right. \\
& \left.+\eta_{0, n}{ }^{C}\right\} \cdot \delta \eta_{F}{ }^{C}-\left\{P^{S} \cdot\left(\eta_{F}{ }^{S}-\eta_{0}{ }^{S}\right)\right. \\
& \left.\left.+P^{C} \cdot\left(\eta_{F} S-\eta_{0}{ }^{S}\right)+\eta_{0}, n^{S}\right\} \cdot \delta \eta_{F}{ }^{S}\right] d S \\
& =0
\end{aligned}
$$

\section{（3） 有限要素法定式化}

こうして得られた沉関数を用いて FEM マトリックス 方程式を導く. 汎関数 (26) の第 1 項から得られるマト リックスは別論文 31）と同様であるので省略し，第 2

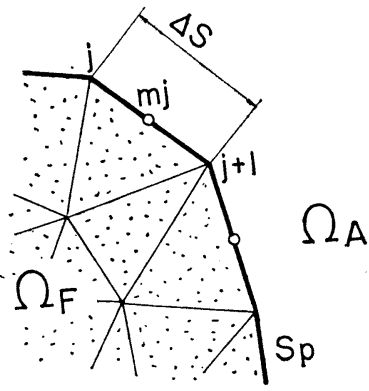

Fig. 2 Discretization in FEM region and on Pseudo Boundary

* 式 (26) の第 1 項がない場合には，汎関数 $\chi$ は次の形とな る.

$$
\chi=\frac{1}{2} \int_{S_{P}}\left(\eta_{S, n} \cdot \eta_{S}+2 \eta_{0, n} \cdot \eta_{S}\right) d S
$$

これは，速度ポテンシャル $\phi$ で表わされた次の別所の変分 沉関数 ${ }^{29}$ に対応する。

$$
J=\frac{1}{2} \int_{S}\left(\phi, n \cdot \phi-2 v_{0} \cdot \phi\right) d S
$$

ただし， $S$ は船体表面， $v_{0}$ は $S$ に垂直方向の与えられた 速度である.また，このような变分原理の利用については， 最近 Zienkiewicz ${ }^{30}$ \& boundary solution procedure $と$ 名ゔけて論じている.
項のマトリックス表示について詳しく述べる.

積分方程式 (23) において Fig. 2 に示すように境界 $S_{P}$ を $N P$ 個の辺に等分割し, 各辺の中点 $m j$ をコントロ 一ル・ポイントとして近似的に積分を離散化表示する.

$$
\begin{aligned}
\eta^{S}\left(\xi_{m i}, \zeta_{m i}\right)= & \frac{i}{2} \sum_{j=1}^{N P}\left\{\eta_{S}\left(\xi_{m j}, \zeta_{m j}\right)\right. \\
& \cdot G,_{n}\left(\xi_{m i}, \zeta_{m i} ; \xi_{m j}, \zeta_{m j}\right) \\
& -G\left(\xi_{m i}, \zeta_{m i} ; \xi_{m j}, \zeta_{m j}\right) \\
& \left.\cdot \eta_{S,{ }_{n}}\left(\xi_{m j}, \zeta_{m j}\right)\right\} \cdot \Delta S \ldots \ldots
\end{aligned}
$$

ここで, $\left(\xi_{m j}, \zeta_{m j}\right)$ は第 $j$ 離散化要素中点 $m j$ の座 標, $\Delta S$ は要素長であり，また，

$$
G= \begin{cases}H_{0}{ }^{(2)}\left(k r_{m i, m j}\right) & (m i \neq m j \text { の時 }) \\ 1-i \cdot \frac{2}{\pi}\left(\ln \frac{k \cdot \Delta S}{4}-0.422784\right) & (m i=m j \text { の時 })\end{cases}
$$

$$
G, n= \begin{cases}-k \cdot H_{1}{ }^{(2)}\left(k r_{m i}, m j\right) \cdot \frac{\partial r_{m i}, m j}{\partial n} & (m i \neq m j \text { の時 }) \\ i \cdot \frac{1}{\pi}\left(X_{l l} \cdot Y_{l}-X_{l} \cdot Y_{l l}\right)_{i} & (m i=m j \text { の時 })\end{cases}
$$

ただし。

$$
\begin{aligned}
& \frac{\partial r_{m i, m j}}{\partial n}=-\frac{\xi_{m i}-\xi_{m j}}{r_{m i}, m j} \cdot\left(\frac{\Delta \zeta_{j}}{\Delta S}\right) \\
& +\frac{\zeta_{m i}-\zeta_{m j}}{r_{m i}, m j} \cdot\left(\frac{\Delta \xi_{j}}{\Delta S}\right) \\
& \left(X_{l}\right)_{i}=\left(\frac{\Delta \xi_{i}}{\Delta S}\right), \quad\left(Y_{l}\right)_{i}=\left(\frac{\Delta \zeta_{i}}{\Delta S}\right) \\
& \left(X_{l l}\right)_{i}=\frac{\xi_{m i-1}-2 \xi_{m i}+\xi_{m i+1}}{(\Delta S)^{2}} \\
& \left(Y_{l l}\right)_{i}=\frac{\zeta_{m i-1}-2 \zeta_{m i}+\zeta_{m i+1}}{(\Delta S)^{2}} \\
& r_{m i}, m j=\sqrt{\left(\xi_{m i}-\xi_{m j}\right)^{2}+\left(\zeta_{m i}-\zeta_{m j}\right)^{2}}
\end{aligned}
$$

ここで， $\Delta \xi_{j}, \Delta \zeta_{j}$ はそれぞれ第 $j$ 要素の $\xi, \zeta$ 方向成分 長であり， $H_{0}^{(2)}\left(k r_{m i}, m j\right), H_{1}{ }^{(2)}\left(k r_{m i}, m j\right)$ はそれぞれ 0 次および 1 次の第 2 種 Hankel 関数である.

中点 $m j, m j-1$ と節点 $j, j+1$ において, 次の関係 がある・

$$
\left.\begin{array}{rl}
\eta_{S}\left(\xi_{m j}, \zeta_{m j}\right)=\left\{\eta_{S}\left(\xi_{j}, \zeta_{j}\right)+\eta_{S}\left(\xi_{j+1}, \zeta_{j+1}\right)\right\} / 2 \\
\eta_{S, n}\left(\xi_{j}, \zeta_{j}\right) \cdot \Delta S= & \left\{\eta_{S,{ }_{n}}\left(\xi_{m j-1}, \zeta_{m j-1}\right) \cdot \Delta S\right. \\
& \left.+\eta_{S,{ }_{n}}\left(\xi_{m j}, \zeta_{m j}\right) \cdot \Delta S\right\} / 2
\end{array}\right\}
$$

式 (31) に式 (38) を適用し, さらに式 (7), (12), （13）を考慮すると，仮想境界 $S_{P}$ 上での $\eta_{F}{ }^{c}, \eta_{F} s$ の 関係式が次のように得られる。

$$
\begin{aligned}
& \left\{\begin{array}{l}
\eta_{F},{ }_{n}{ }^{C} \\
\eta_{F},{ }_{n}
\end{array}\right\}=\left[\begin{array}{rr}
-P^{C C} & -P^{C S} \\
P^{S C} & P^{S S}
\end{array}\right] \\
& \cdot\left(\left\{\begin{array}{l}
\eta_{F}{ }^{C} \\
\eta_{F} S
\end{array}\right\}-\left\{\begin{array}{l}
\eta_{0}{ }^{C} \\
\eta_{0} s
\end{array}\right\}\right)+\left\{\begin{array}{l}
\eta_{0, n}{ }^{C} \\
\eta_{0, n} s
\end{array}\right\}
\end{aligned}
$$


ただし， $\eta_{F}{ }^{c}$ などは節点の $\eta_{F}{ }^{c}$ などを成分とするべ タトル（式 (49)，(50)) である. また， $\boldsymbol{P}^{C C}$ などは式 (25) の $P^{C}$ などに対応するマトリックスであり, 次式 で与えられる.

$$
\begin{aligned}
{\left[\begin{array}{ll}
P^{c C} & P^{c s} \\
P^{s c} & P^{s s}
\end{array}\right]=} & K^{T} \cdot\left(\left[\begin{array}{rr}
G^{C} & G^{S} \\
G^{S} & -G^{c}
\end{array}\right]\right. \\
& \left.\cdot\left[\begin{array}{lr}
G N^{C} & -G N^{s} \\
G N^{S} & G N^{c}
\end{array}\right]\right) \cdot K
\end{aligned}
$$

ここで, $\boldsymbol{G}^{\boldsymbol{C}}, \boldsymbol{G} \boldsymbol{N}^{\boldsymbol{C}}$ などは $G, G,{ }_{n}$ により構成されるマ トリックスであり, その成分は次式で与えられる.

$$
\begin{aligned}
& G^{C}{ }_{(m i, m j)} \\
& =\left\{\begin{array}{lr}
\frac{1}{2} \cdot Y_{0}\left(k r_{m i, m j}\right) & (m i \neq m j) \\
\frac{1}{\pi} \cdot\left(\ln \frac{k \cdot \Delta S}{4}-0.422784\right) & (m i=m j)
\end{array}\right. \\
& G_{(m i, m j)}^{S}= \begin{cases}\frac{1}{2} \cdot J_{0}\left(k r_{m i, m j}\right) & (m i \neq m j) \\
\frac{1}{2} & (m i=m j)\end{cases}
\end{aligned}
$$

$$
G N^{C}{ }_{(m i, m j)}
$$

$$
= \begin{cases}N_{(m i, m j)} \cdot Y_{1}\left(k r_{m i, m j}\right) & (m i \neq m j) \\ -\frac{1}{2 \pi}\left(X_{l l} \cdot Y_{l}-X_{l} \cdot Y_{l l}\right)_{i} \cdot \Delta S-1 & (m i=m j)\end{cases}
$$

$$
G N_{(m i, m j)}^{S}=\left\{\begin{array}{lr}
N_{(m i, m j)} \cdot J_{1}\left(k r_{m i, m j)}\right. & (m i \neq m j) \\
0 & (m i=m j)
\end{array}\right.
$$

ただし，

$$
\begin{aligned}
N_{(m i, m j)}= & -\frac{k}{2} \cdot\left\{-\frac{\xi_{m i}-\xi_{m j}}{r_{m i, m j}} \cdot \Delta \zeta_{j}\right. \\
& \left.+\frac{\zeta_{m i}-\zeta_{m j}}{r_{m i, m j}} \cdot \Delta \xi_{j}\right\} \cdots \cdots
\end{aligned}
$$$$
(m i, m j=1, \cdots, N P)
$$

であり， $J_{0}, J_{1}$ はそれぞれ0次および 1 次の Bessel 関 数， $Y_{0}, Y_{1}$ はそれぞれ0次および 1 次の Neumann 関 数である.

また, $\boldsymbol{K}$ は中点 $(m j)$ 関俰式から節点 $(j)$ 関俰式へ の変換マトリックス式であり, 次式で与えられる.

$$
\begin{aligned}
& K=\left[\begin{array}{cc}
K_{1} & 0 \\
0 & K_{1}
\end{array}\right]
\end{aligned}
$$

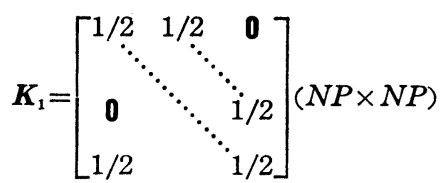

基本波ベクトルは次式で与えられる.

$$
\begin{aligned}
& \eta_{0}{ }^{C}=\left\{\eta_{0}{ }^{C}(j)\right\}^{T}=\left\{a_{I} \cdot \cos k \rho(j)\right\}^{T} \cdots \cdots(45 \cdot \mathrm{a}) \\
& \eta_{0}{ }^{S}=\left\{\eta_{0}{ }^{S}(j)\right\}^{T}=\left\{a_{I} \cdot \sin k \rho(j)\right\}^{T} \cdots \cdots(45 \cdot \mathrm{b})
\end{aligned}
$$

$$
\begin{aligned}
\eta_{0, n}{ }^{c} & =\left\{\eta_{0, n}{ }^{c}(j) \cdot \Delta S\right\}^{T} \\
& =\left\{-a_{I} k \rho, n(j) \cdot \sin k \rho(j) \cdot \Delta S\right\}^{T} \cdots(46 \cdot \mathrm{a}) \\
\eta_{0, n}{ }^{S} & =\left\{\eta_{0, n}{ }^{s}(j) \cdot \Delta S\right\}^{T} \\
& =\left\{a_{I} k \rho_{, n}(j) \cdot \cos k \rho(j) \cdot \Delta S\right\}^{T} \cdots \cdots(46 \cdot \mathrm{b})
\end{aligned}
$$

ここで,

$$
\begin{gathered}
\rho(j)=\xi_{j} \cos \alpha+\zeta_{j} \sin \alpha \cdots \ldots \ldots \ldots \ldots \ldots \ldots . \cdots \\
\rho_{n}(j)=-\left(\frac{\Delta \xi_{j}}{\Delta S}\right) \cdot \cos \alpha+\left(\frac{\Delta \zeta_{j}}{\Delta S}\right) \cdot \sin \alpha \cdots
\end{gathered}
$$

ただし， $a_{I}, \alpha$ はそれぞれ入射波振幅絶対值および入 射角 ( $x$ 軸から反時計回りを正にとる) である.

また, 先に述べたように,

$$
\begin{aligned}
& \eta_{F}{ }^{c}=\left\{\eta_{F}{ }^{c}(j)\right\}^{T} \\
& \eta_{F} S=\left\{\eta_{F}{ }^{S}(j)\right\}^{T} \\
& \eta_{F, n}{ }^{C}=\left\{\eta_{F, n}{ }^{C}(j) \cdot \Delta S\right\}^{T} \\
& \eta_{F, n}{ }^{S}=\left\{\eta_{F, n} S(j) \cdot \Delta S\right\}^{T} \\
& (j=1, \cdots, N P)
\end{aligned}
$$

式 (39) と式 (25) の対応を考えると, 汎関数 (26) の第 2 項は結局次のようになる.

$$
\begin{aligned}
\chi_{P}= & \left\{\eta_{F} c T, \eta_{F} s T\right\} \cdot\left(\left[\begin{array}{ll}
P^{C C} & P^{c s} \\
P^{S C} & P^{S s}
\end{array}\right]\right. \\
& \left.\cdot\left(\frac{1}{2}\left\{\begin{array}{l}
\eta_{F} c \\
\eta_{F} s
\end{array}\right\}-\left\{\begin{array}{l}
\eta_{0}^{c} \\
\eta_{0} s
\end{array}\right\}\right)-\left\{\begin{array}{l}
\eta_{0, n}{ }^{c} \\
\eta_{0, n} s
\end{array}\right\}\right)
\end{aligned}
$$

最終的に変分原理を適用すれば次の汎関数 $\chi$ の停留条 件,

$$
\begin{aligned}
\frac{\partial \chi}{\partial \eta_{F}{ }^{c}(m)}= & 0, \quad \frac{\partial \chi}{\partial \eta_{F}{ }^{S}(m)}=0 \\
& (m=1, \cdots, M) \quad M: \text { 全節点数 }
\end{aligned}
$$

から, 次のマトリックス方程式が得られる.

$$
\begin{aligned}
& \left(\left[\begin{array}{rr}
D & 0 \\
0 & -D
\end{array}\right]+\left[\begin{array}{ll}
\boldsymbol{P}^{C C} & \boldsymbol{P}^{C S} \\
\boldsymbol{P}^{S C} & \boldsymbol{P}^{S S}
\end{array}\right]\right) \cdot\left\{\begin{array}{l}
\eta_{F}{ }^{c} \\
\eta_{F} s
\end{array}\right\} \\
& =\left[\begin{array}{ll}
\boldsymbol{P}^{c c} & \boldsymbol{P}^{c s} \\
\boldsymbol{P}^{s c} & \boldsymbol{P}^{s s}
\end{array}\right] \cdot\left\{\begin{array}{l}
\eta_{0}{ }^{c} \\
\eta_{0} s
\end{array}\right\}+\left\{\begin{array}{r}
\eta_{0, n}{ }^{c} \\
-\eta_{0, n} s
\end{array}\right\}
\end{aligned}
$$

ここで, $\boldsymbol{D}$ は汎関数 (26) の第 1 項から得られるマト リックスである.

これを解くことにより全節点における $\eta_{F}{ }^{c}(m), \eta_{F} s$ $(m)$ が求まり, 最終的に $\eta_{F}(m)$ が定められる. $S_{P}$ 上 における $\eta_{F}$ を知れば, 式 (13) および式 (22) から $\Omega_{A}$ 内の $\eta_{S}$ を求めることができる.

\section{3. 数値計算例}

\section{（1） 円柱による回折散乱波の解析}

円柱による波の回折問題は, 平面 2 次元波の回折問題 の中で最も基本的なものである. これに対しては古くか ら, 音波の回折問題として Fourier-Bessel 展開法を用 いた解析が行われており，これを水波に応用した Mac 


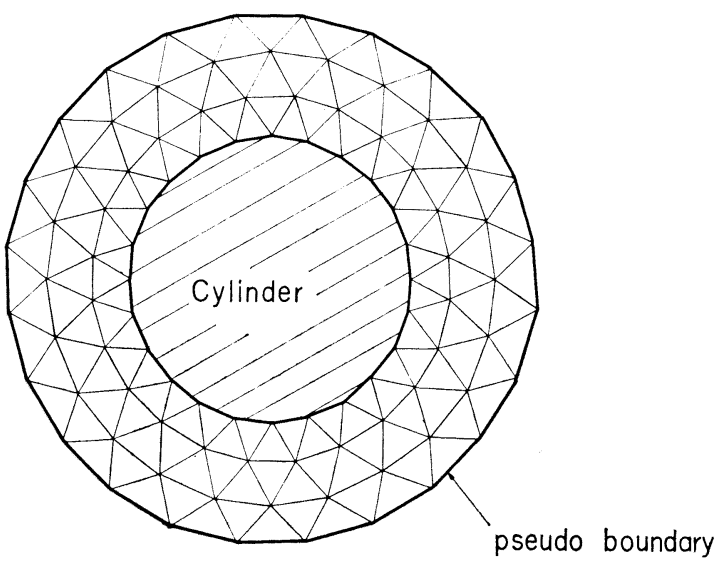

Fig. 3 Mesh Division around a Cylinder

Camy and $\mathrm{Fuchs}^{8)}$ や田中9)の研究がよく知られている.

これに対して，ここでは FEMによる解析を行い，前 記の級数展開法と比較することによりその妥当性を検討

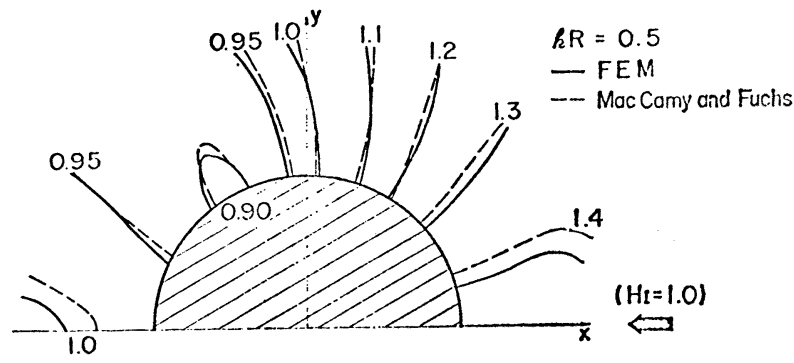

Fig. 4 Comparison between FEM and Fourier-Bessel Expansion Solutions of Wave Amplitude $(k R=0.5)$

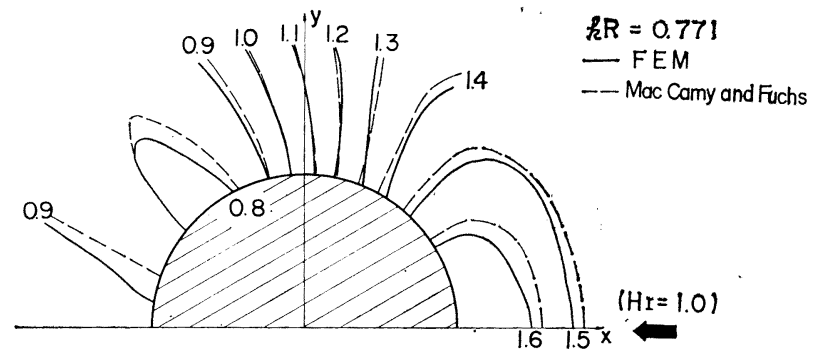

Fig. 5 Comparison between FEM and Fourier-Bessel Expansion Solutions of Wave Amplitude $(k R=0.771)$

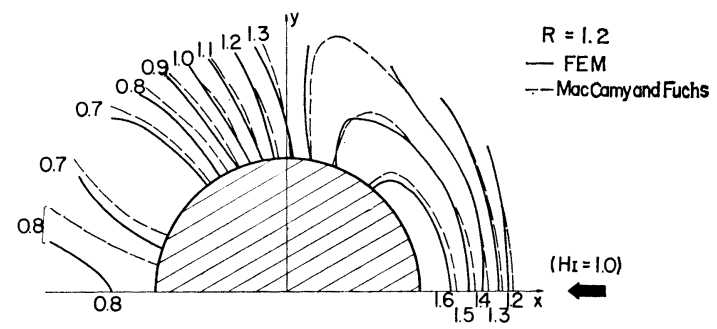

Fig. 6 Comparison between FEM and Fourier-Bessel Expansion Solutions of Wave Amplitude $(k R=1.2)$

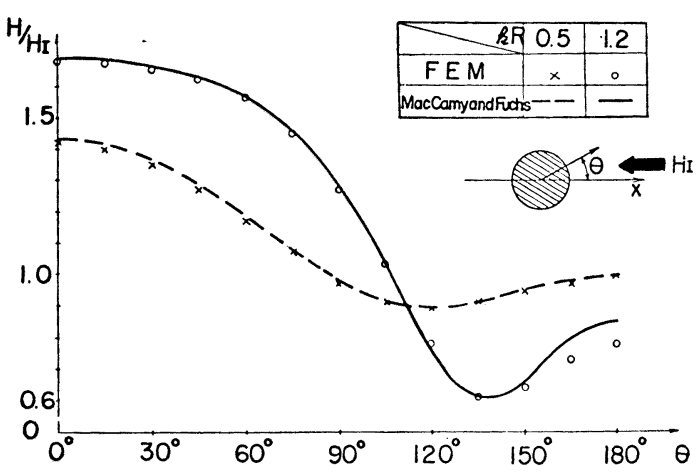

Fig. 7 Wave Amplitude Around the Cylinder

する. Fig. 3 に円柱周囲のメッシュ分割を示す. 仮想 境界 $S_{P}$ は円柱の周囲の適当な位置に設けられている.

$S_{P}$ の外側は無限に広がる open sea であり $\Omega_{A}$ に相当 する. $S_{P}$ と円柱に囲まれた領域が $\Omega_{F}$ であり, 有限要 素分割されている．前述したように $S_{P}$ 形状は一般に任 意であるが，ここでは円形とすることにより慣用 変分原理の適用が可能となり, マトリックスは対 称となる.また $\Omega_{F}$ 内では任意の水深変化を考慮 できるが，ここでは全領域で水深一定とする.

解析結果を Fig. 4, 5 および 6 に示す.これ らは，波高 1.0 , 角波数 $k$ の入射波が矢印の方向 に進行した場合の半径 $R$ の円柱周辺波高分布に ついて, FEM 解と MacCamy and Fuchs の解 を比較したものである.これらをみると，いずれ の場合も両者はほぼ良く一致していることがわか る. Fig. 7 は, $k R$ が 0.5 および 1.2 の場合の 円柱壁面に沿った波高について FEM 解と Mac Camy and Fuchs 解を比較したものである。こ れより， $k R$ が 0.5 の場合のように入射波長が円 柱径に比して長い時には両者は良く一致している が， $k R$ が 1.2 の場合のように入射波長が相対的 に短くなると, 円柱後方に若干の差がみられるこ とがわかる。

以上により，FEM 解は十分妥当な值を与える ことがわかる. ただし，Fig. 3 のようなメッシ 工分割の場合, $k R$ が 1.2 程度になると円柱後方 に乱れが生ずるので，波長とメッシュ分割の関係 には十分注意が必要である。

\section{（2）楕円柱による回折散乱波の解析}

楕円柱による波の回折問題においても, 級数展 開法が用いられる。この場合には棈円筒座標を用 いることから，円柱の場合の Hankel 関数に対応 するものとして Mathieu 関数が現われる.この 方法は音波の回折問題の研究において古くから用 いられていたが，合田・吉村・伊藤 ${ }^{11}$ は船体およ 


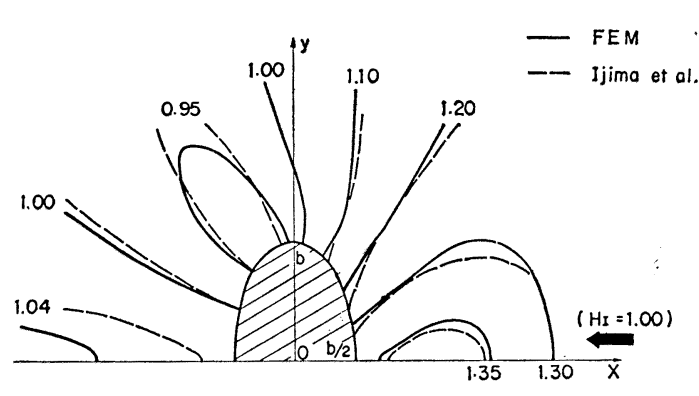

Fig. 8 Comparison between FEM and Integral Equation Solutions of Wave Amplitude $(k b=0.522)$

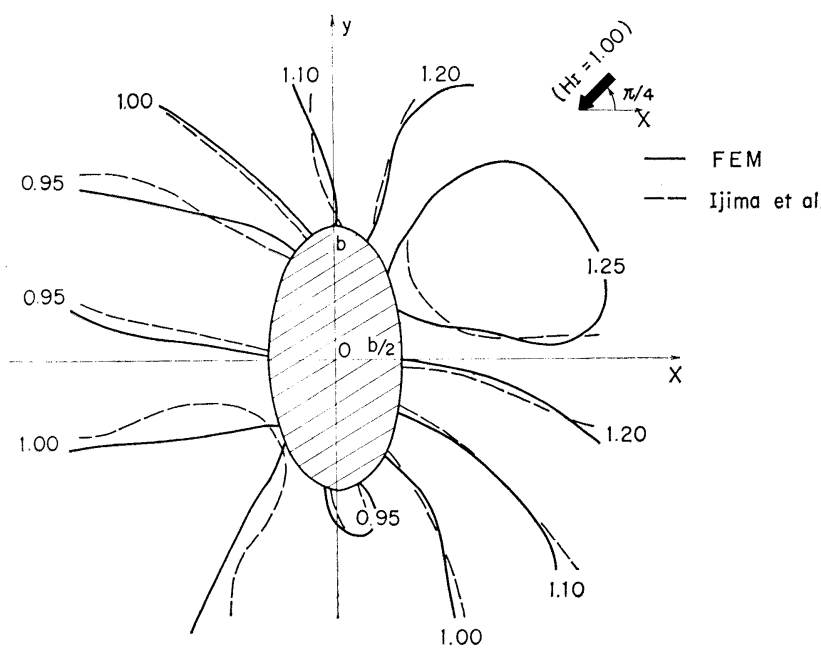

Fig. 9 Comparison between FEM and Integral Equation Solutions of Wave Amplitude $(k b=0.522)$

び島堤周辺の波動解析に適用している.これに対して， 最近では積分方程式を離散化して解を求める井島ら ${ }^{17)}$ 解析結果も得られている.この場合には, Mathieu 関数 のような複雑な関数を用いずに解析することができる.

ここでは FEMによりこの問題を解析し, 井島らの結 果と比較検討することとする. 一定水深の水中に設置さ れた長径 $2 b$, 短径 $b$ の棈円柱に対する解析結果を Fig. 8 以下に示寸. 入射波は波高 1.0 , 角波数 $k$ で矢印の方

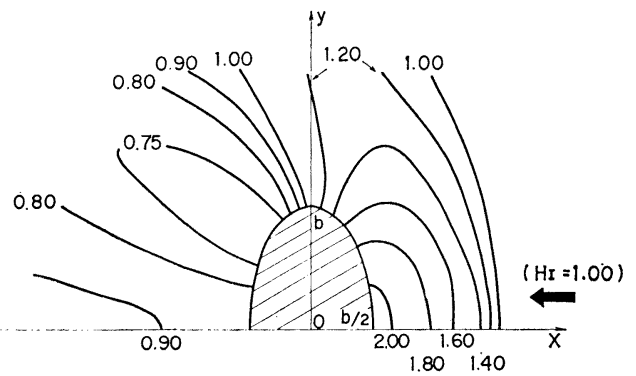

Fig. 10 Comparison between FEM and Integral Equation Solutions of Wave Amplitude $(k b=1.044)$

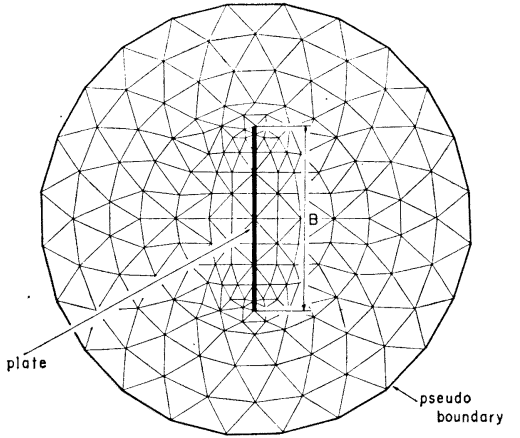

Fig. 11 Mesh Division around a Rectangular Pile

向に進行するものとする. Fig. 8 および 9 は $k b$ が 0.522 の場合の波高分布の FEM 解を井島らの 解と比較して示したものである.これより，両 者はかなり良く一致していることがわかる．円 柱の場合と同様，棈円柱の後方に若干のずれが 見られる，両図を比較すると，波が楕円長軸に 直角に入射する場合の方が， $\pi / 4$ で入射する場 合よりも波高が大きくなることが確認される.

Fig. 10 は， $k b$ が 1.044 の場合の波高分布で ある. Fig. 8 と比較して入射波長が短くなっ ているため，回折散乱現象がより顕著に現われ ている.

\section{（3）長方形柱による回折散乱波の解析}

円柱および棈円柱の問題に対しては，それぞ れ円筒および棈円筒座標を用いることにより， 変数分離の後に級数展開を行ら解析方法が適用 できた.しかし，その他の任意形状の柱に対しては，® はやこのような解析的方法は適用不可能である.これに 対して, 積分方程式法は任意形状柱による回折問題に適 用可能であり，長方形柱に対しても井島らの解析例があ る. この場合, 長方形隅角部のような不連続部に対して は, 積分方程式の離散化を細かくする必要がある.

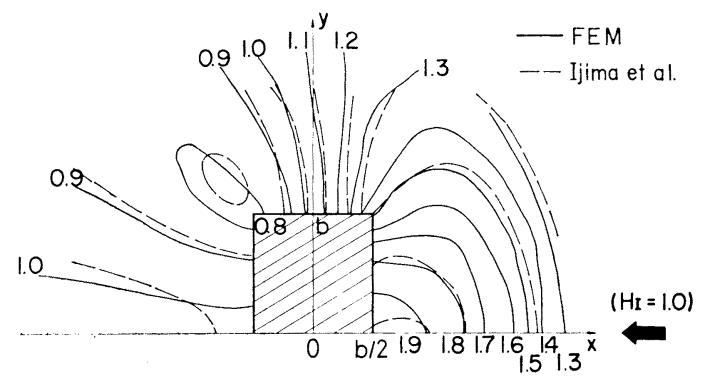

Fig. 12 Comparison between FEM and Integral Equation Solutions of Wave Amplitude $(k b=0.771)$ 


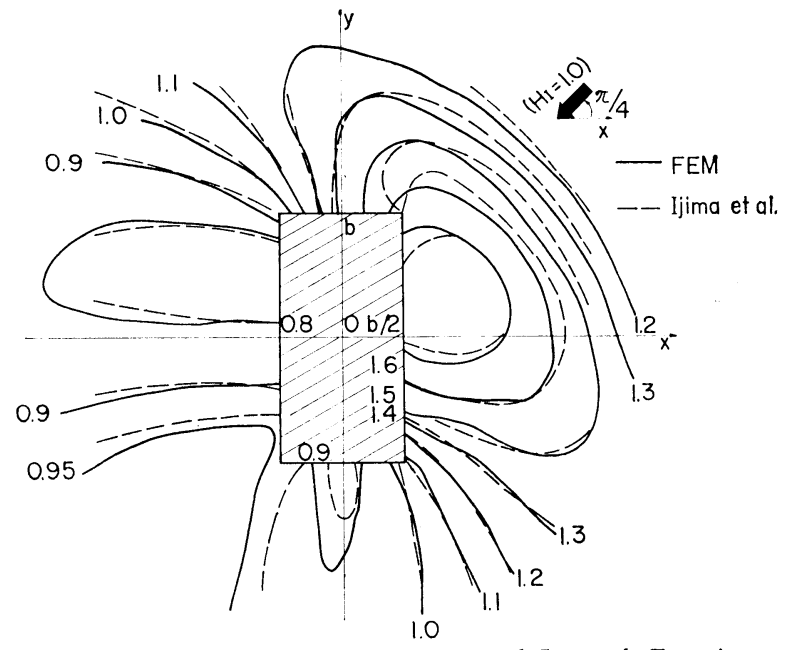

Fig. 13 Comparison between FEM and Integral Equation Solutions of Wave Amplitude $(k b=0.771)$

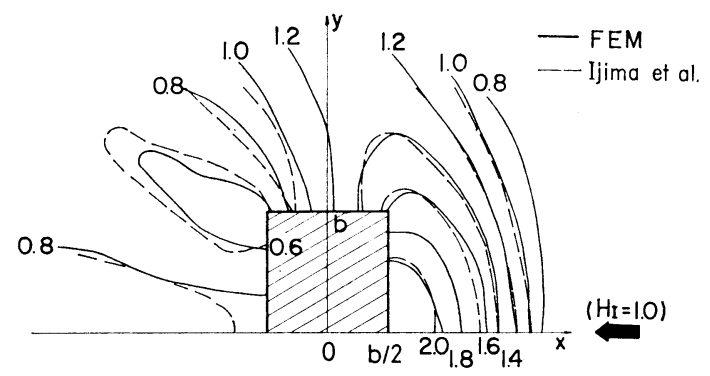

Fig. 14 Comparison between FEM and Integral Equation Solutions of Wave Amplitude $(k b=1.2)$

ここでは, 1 辺 $b$, 他辺 $2 b$ の長方形柱の問題を FEM 解析する. Fig. 11 にメッシュ分割を示す.この場合隅 角部においては，積分方程式法と同様に回折波を十分表 現し得るよう局部的に分割を細かくした．Fig. 12, 13 および 14 に長方形柱周辺波高分布の FEM 解析結果 を，積分方程式法による井島らの解と比較して示す. い ずれの場合も，両者はかなり良く一致していることがわ

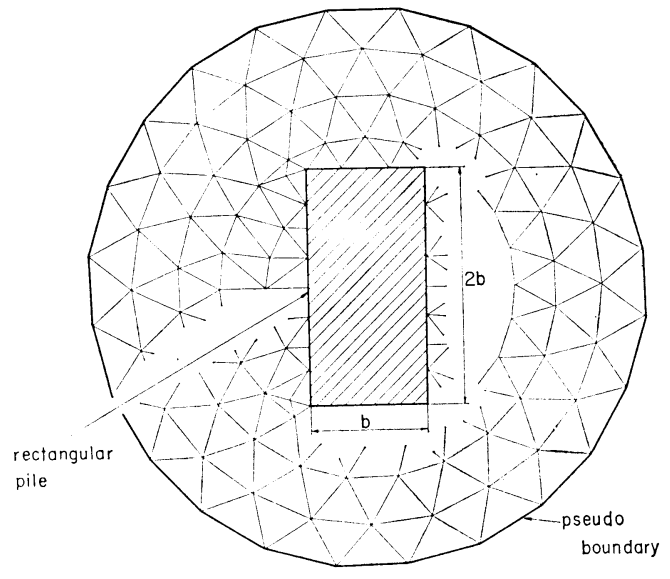

Fig. 15 Mesh Division around a Plate
かる．また，当然のことながら，直角入射の場合 および入射波長が短い場合に長方形柱前面波高が 高くなり，完全反射の場合の波高 2.0 に近ゔくこ となどが確認され，結果は妥当なものと思われ る.

\section{（4）平板による回折散乱波の解析}

この問題は，棈円柱の場合の級数解法におい て，棈円柱の厚さを 0 にすることにより解析解が 得られる.この方法は, 古くリボンによる音波の 回折問題を解析するのに用いられているが，合 田・吉村 ${ }^{11)}$ はこの方法を用いて離岸堤による波の 回折問題を検討している.

ここでは，Fig. 15 に示すような平板モデルを FEM により解析することとした，平板端部の特 異性を考虑して，この付近のメッシュ分割を相当 に細かくした. Fig. 16 および 17 に解析結果を示す. これは, 平板長 $B$ と入射波長 $L$ の比 $B / L$ が 0.166 の 場合の回折状況を示すものである. 棈円柱および長方形 柱の場合と同様，直角入射の場合の方が波高が全体的に

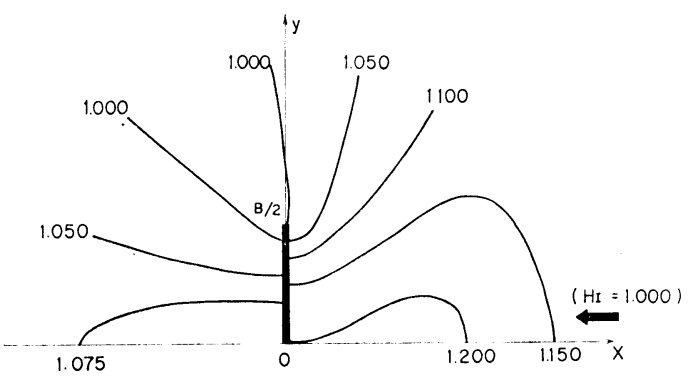

Fig. 16 Wave Diffraction Around the Plate $(B / L=0.166)$

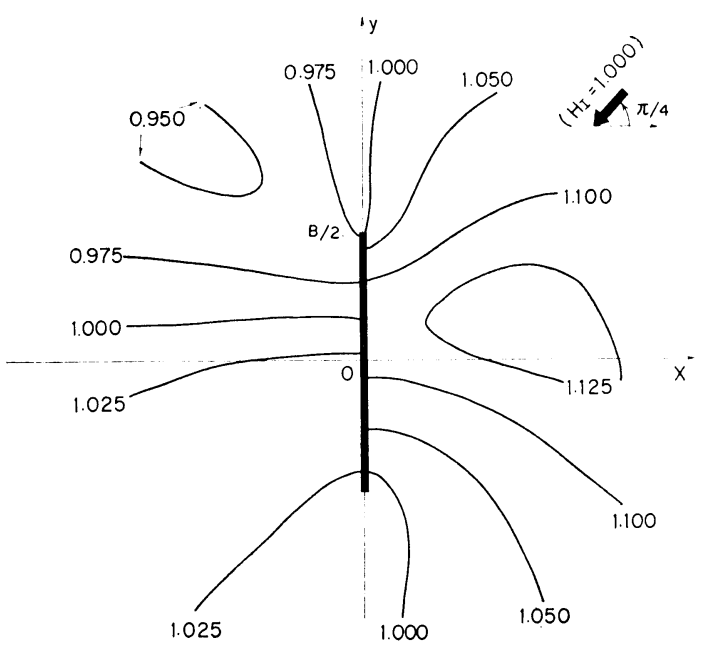

Fig. 17 Wave Diffraction Around the Plate $(B / L=0.166)$ 
大きいが，平板裏側ではいずれもほぼ一様で入射波高 1.0 に近い. 一般に離岸堤は，堤長の 2 倍以上の波長の 波に対してはしゃへい効果がないといわれているが，本 解析結果はこれに符合している. また, 直接の比較は行 っていないが，傾向は合田らの結果とよく似ている.

なお, 平板端は本報で採用した理論上では本来無限大 の波高を持つ特異点である.しかし，FEM のような近 似解ではこれを綮密に表現することはできない，これに 関する注意は後述する.

\section{4.あとがき}

本論文は, 地形および構造物による波の回折散乱現象 を, FEM 解析する方法について述べたものである.こ こで問題となることは, 解析領域が無限領域になる点で ある.これに対してここでは, 解析関数を FEM に接続 させて, FEM 解析領域を有限化することにした．両者 の接続にあたっては, Greenの公式から導かれる積分方 程式を境界条件とする変分原理が用いられた.

本手法の妥当性を検討するために，まず円柱による回 折散乱問題を解析した. 結果を級数解と比較することに より，十分満足できる解が得られることを示した．続い て, 楕円柱, 長方形柱抢よび平板による回折散乱問題を FEM 解析し, 積分方程式法による井島らの解と同じ結 果が得られることを示した.

本手法の特徵は, 地形および任意形状構造物に上る波 の回折散乱挙動を, 水深変化を忠実に考虑しつつ, 簡便 に解析し得ることである. 一方, 今後改善が望まれる点 として, 精度向上および自由度低減があげられるが, こ れ対しては高精度要素の利用が考えられる．また，防波 堤端部のよう特異点の取扱い方も問題になる.このよう な特異性の表現においては, FEM のような近似解より も，その特異性を含み得る解析解の方が好ましい，この 点から, Chen and $\mathrm{Mei}^{24)}$ のように, 外部領域ばかりで なく内部領域においても解析解を利用することが考えら れる. その際にも, 本論の変分原理の適用によって,

FEM と解析解をつなぐことが可能である.

1）参 考 文 献 3 報)一地形および構造物による波の散乱について一, 第 22 回海岸工学講演会論文集, 1975.

2) Stoker, J.J. : Water Waves, Interscience Publishers, 1957.

3) Penny, W.G. and Price, A.T. : Diffraction of Sea Waves by Breakwaters, Artificial Harbors, Dire. Misc, Weapon Develop. Tech. Hist., No. 26, 1944.

4) Puttnam, J.A. and Arthur, A.T. : Diffraction of Water Waves by Breakwaters, Trans. A.G.U., Vol. 29, No. 4, 1948.

5) Blue, F.L. and Johnson, J.W. : Diffraction of Water
Waves Passing through a Breakwater Gap, Trans. A.G.U., Vol. 30, No. 5, 1949.

6）田中 清: 防波堤の水理, 水丁学の最近の進歩, 土木学 会, 1953 .

7）三井 宏ほか：海䓍構造物不連続部の波高分布について (符 1 報〜第 6 報)，第 13 回〜22 回海岸工学講演会論文 集, 1966 1975.

8) MacCamy, R.C. and Fuchs, R.A. : Wave Force on Piles; Diffraction Theory, Tech. Memo. No. 69, $\mathrm{BEB}, 1954$.

9）田中 清: 円形自による波浪の回折，第 3 回海岸工学講 演会講演集, 1956 .

10) Momoi, T. : A Long Wave around a Breakwater (Case of Perpendicular Incidence)[III], Bull. Earthq, Res. Inst., Univ. of Tokyo, 46, 1968.

11）合田良実・吉村知司：島堤および大型䅋円柱体による波 の散乱と波力について, 土木学会論文報告集, 第 205 号, 1972 年 9 月.

12) 和田 明: 回折問題の一解法についた, 第 11 回海岸工学 講演会講演集, 1964 .

13) Biesel, F. et Ranson, B. : Calcul de la Diffraction de la Houle, AIRH, Dubrovnik, 1961.

14) Barailler, L. et Gaillard, D. : Evolution Récente des Modéles Mathématéques d'agitation due a la Houle; Calcul de la Diffraction en Profondeur non Uniforme, La Houille Blanche, No. 8, 1967.

15) Lee, J.J. : Wave Induced Oscillation in Harbors of Arbitrary Geometry, J. Fluid Mech., Vol. 45, Part $2,1971$.

16) Daubert, A. et Lebreton, J.C. : Diffraction de la Houle sur des Obstacles a Parois Verticales, La Houille Blanche, Vol. 20, No. 4, 1965.

17）井島武士・周 宗仁・湯村や卞・田淵幹修：任意形状の 透過抢よび不透過防波堤による波の散乱, と波力, 第 20 回 海岸工学講演会論文集, 1973 .

18）日野幹雄・宮永洋一：グリーン関数および仮想法による 波力と波の回折計算, 土木学会論文報告集, 第 237 号, 1975.

19）伊藤喜行・谷本勝利：数值波動解析とその忘用一構造物 周辺の波一, 第 18 回海岸工学講演会論文集, 1971 .

20）坂井藤一・河合三四郎：波動解析への有限要素法の適用, 第 20 回海岸工学講演会論文集, 1973.

21) Wehausen, J.V. and Laitone, E.V. : Surface Waves, Encyclopedia of Physics, Vol. IX, Springer Verlag, 1960 .

22) Zienkiewicz, O.C. : The Finite Element Method and Boundary Solution Procedures as General Approximation Method for Field Problems, Advanced Topics in Finite Element Analysis, Chap. 9, Mark Analysis Res. Corp., 1975.

23) Bai, K.J. : A Variational Method in Potential Flows with a Free Surface, Rep. No. NA 72-2, Univ. of California, Berkeley, Sept. 1972.

24) Berkhoff, J.C.W. : Computation of Combined Refraction-Diffraction, Proc. of 13th Coastal Eng., Vol. $2,1972$.

25) Chen, H.S. and Mei, C.C. : Oscillations and Wave Forces in a Man-Made Harbor in the Open Sea, 10th Symp. in Naval Hydro., Office of Naval Res. 1974.

26) Bai, K.J. and Yeung, R. : Numerical Solutions of Free-Surface and Flow Problems, 10th Symp. in Naval Hydro., Office of Naval Res. 1974.

27）瀬戸秀幸・山本善之：有限要素法による定常波動問題り 
基礎的研究，日本造船学会論文集，第 136 告，1974.

28）鰓津久一郎・池川昌弘：有限要素法の揚力面理論への忍 用，マトリックス構造解析法研究発表論文集，1973.

29) Bessho, M. : Variational Approach to Steady Ship Wave Problem, 8th Symp. in Naval Hydro., 1970.

30) Zienkiewicz, O.C. and Bettess, P. : Infinite Elements in the Study of Fluid-Structure Interaction Problems, 2nd Int. Symp. on Computing Methods in Applied Science and Engineering, Versailles, Dec. 1975.

31）坂井藤一.月岡康一：湾水振動の有限要素解析法, 土木 学会論文報告集 (投稿準備中). 